\title{
Green economies and green jobs: implications for South Africa
}

\author{
G. Nhamo \\ Centre for Corporate Citizenship, University of South Africa, \\ South Africa
}

\begin{abstract}
The term 'green' is often (mis)used in a number of ways. For example, we talk and hear of green buildings, green financing, green economies, green wash, green accounting, green schools, green agriculture, green tourism, green procurement, green ITC, the list goes on. In this paper, we address twin, but closely linked, green terms: 'green economy' and 'green jobs' and their implications for an emerging economy like South Africa. The paper conceptualises the transition to green economies and how this impacts on the jobs market in South Africa.
\end{abstract}

Keywords: green economy, green jobs, South Africa.

\section{Introduction}

A landmark and comprehensive publication in the area of green economies and green jobs is a 2008 joint document titled Green Jobs: Towards Decent Work in a Sustainable, Low-Carbon World produced by the United Nations Environment Programme (UUNEP), International Labour Organisation (ILO), International Organization of Employers (IOE), International Trade Union Confederation (ITUC). The publishers claim that the publication is in large part as a result of climate change (CC) and the need to meet greenhouse gas (GHG) emission reduction targets under the UN Framework Convention on Climate Change (UNFCCC) and the Kyoto Protocol market based mechanism (UNEP et al. [1]). The need to urgently address $\mathrm{CC}$ has led to changing patterns of investment flows leading to investment into areas from renewable energy generation up to energy efficiency projects at the household and industrial level. Many green jobs have been created during the transition to green economies. For example, a 
project in Bangladesh, training local youths and women as certified solar technicians and as repair and maintenance specialists, aims to create some 100,000 jobs. In India, an initiative to replace inefficient biomass cooking stoves in nine million households with more advanced ones could create 150,000 jobs (UNEP et al. [1 p. vii]). Many more green jobs are projected into the future of which the South African economy must be party to.

\section{Green economies}

Green economies are so-called because they exhibit high levels of jobs created to address a myriad of environmental concerns. In an ideal state of affairs, a green economy is one that does not generate pollution or waste and is hyper-efficient in its use of energy, water, and materials. Green economies are also exemplarily in terms of the manner in which a deliberate and calculated move towards low carbon emissions is made, thereby creating low-carbon economies and those that we can consider to be climate change compliant. To achieve the low-carbon economy status, innovative ways of thinking are getting embedded in Low Carbon Growth Plans (LCGP), like South Africa's DEAT [2], through the Long Term Mitigation Strategy (LTMS) that needs to be complemented by a similar initiative possibly for a Long Term Adaptation Strategy and the National Climate change Response Strategy.

A transition to green economies implies four major scenarios in terms of jobs UNEP et al. [1 p. 3]:

1. In some cases, additional jobs will be created - as in the manufacturing of pollution-control devices added to existing production equipment.

2. Some employment will be substituted - as in shifting from fossil fuels to renewables, or from truck manufacturing to rail car manufacturing, or from landfilling and waste incineration to recycling.

3. Certain jobs may be eliminated without direct replacement - as when packaging materials are discouraged or banned and their production is discontinued.

4. It would appear that many existing jobs (especially such as plumbers, electricians, metal workers, and construction workers) will simply be transformed and redefined as day-to-day skill sets, work methods, and profiles are greened.

The four bullets highlighted above are special for South Africa. When the cost-benefit analysis of the green jobs is done for the country these facets need to be taken into consideration. It terms of skills development, the workers highlighted under bullet 4 will require 'greening' (Figure 1).

Chapple [3 p. 1] maintains that at basic level, a green economy is a clean energy economy comprising primarily four sectors: renewable energy (e.g., solar, wind, geothermal); green building and energy efficiency technology; energy-efficient infrastructure and transportation; and recycling and waste-toenergy. In terms of policy and legal frameworks, national governments must ensure that these result in the provision of funding of green projects, including infrastructure development where the private sectors lack UNEP et al. [1]. 
Additional jobs created - e.g. In manufacturing pollution-control devices added to existing production equipment.
Some employment will be substituted e.g. shifting from fossil fuels to

renewables, or from truck manufacturing to rail car manufacturing, or from landfilling to recycling.
Existing jobs transformed \& redefined as

they get greened (e.g. plumbers, electricians, metal workers \& construction workers).
Jobs \& transition to

Green Economies

Figure 1: Green jobs and transition to green economies. Source: author.

Governments must create and maintain a level playing field for all actors and among major policies can be listed UNEP et al. [1 p. 5]:

- Subsidies: Phase out subsidies for environmentally harmful industries, and shift a portion or all of those funds to renewable energy, efficiency technologies, clean production methods, and public transit.

- Carbon Markets: Fix the current shortcomings inherent in carbon trading and Kyoto Protocol related innovations like the Clean Development Mechanism so that they can become reliable and adequate funding sources for green projects and employment.

- Tax Reform: Scale up eco-taxes, such as those adopted by a number of European countries, and replicate them as widely as possible. Eco-tax revenues can be used to lighten the tax burden falling on labour while discouraging polluting and carbon-intensive economic activities.

- Targets and Mandates: Ensure that regulatory tools are used to the fullest extent in the drive to develop greener technologies, products, and services - and thus green employment. This includes land-use policies, building codes, energy-efficiency standards (for appliances, vehicles, etc.), and targets for renewable energy production.

- Energy Alternatives: Adopt innovative policies to overcome barriers to renewable energy development, including feed-in laws that secure access to the electrical grid at guaranteed prices.

- Product Take back: Adopt "extended producer responsibility" laws (requiring companies to take back products at the end of their useful life) for all types of products.

- Eco-Labelling: Adopt eco-labels for all consumer products to ensure that consumers have access to information needed for responsible 
purchasing decisions (and hence encouraging manufacturers to design and market more eco-friendly products).

- R\&D Budgets: Reduce support for nuclear power and fossil fuels and provide greater funding for renewable energy and efficiency technologies.

- International Aid: Reorient the priorities of national and multilateral development assistance agencies as well as export credit agencies away from fossil fuels and large-scale hydropower projects toward greener alternatives.

HSBC Global Research cited in WWF [4 p. 6] notes that a $€ 2.2$ trillion worth of global stimulus packages worldwide has been instituted since 2008. Of this, close to $€ 300$ billion addresses climate policy objectives. Europe accounts for $€ 42$ billion of this, or about $13 \%$ of the global total. European stimulus packages provide a boost to Carbon Capture and Storage (CCS) research and low-carbon vehicles and, to some extent, energy efficiency of buildings. The European Commission's Economic Recovery Plan finalised in June 2009 includes, the green cars ( $€ 5$ billion) initiative, energy-efficient buildings, $€ 1$ billion for research and development, and "factories of the future" (€1.2 billion for R\&D). Close to $60 \%$ of the funds were green.

\section{Towards a green jobs definition}

Defining complex issues is always complex. However, in order to provide a solid operational foundation in as far as green jobs perspectives are concerned in South Africa, an attempt will be made to present a number of definitions for such. Green Jobs are defined by the UNEP et al. [1 p. 3] as:

Work in agricultural, manufacturing, research and development (R\&D), administrative, and service activities that contribute substantially to preserving or restoring environmental quality. Specifically, but not exclusively, this includes jobs that help to protect ecosystems and biodiversity; reduce energy, materials, and water consumption through high efficiency strategies; de-carbonize the economy; and minimize or altogether avoid generation of all forms of waste and pollution.

What is of interest here is the fact that the authors identify six key sectors that have a bearing on environmental preservation and restoration. Effectively, these key sectors play a critical role in terms of generation Green Jobs opportunities. Green jobs must be decent work, offering adequate wages, safe working conditions, job security, reasonable career prospects, and worker rights. The movement toward Green Economies is viewed as having more benefits in terms of job opportunities than the disadvantages UNEP et al. [1]. Coincidentally the above definition of green jobs has been adopted by the South African government as it moves towards the development of a national green jobs strategy planned to be finalised in 2010 . 
A study in the USA by Pollin et al. [5] focusing on six infrastructure investment strategies looking at retrofitting buildings to improve energy efficiency, expanding mass transit and freight rail, constructing smart electrical grid transmission systems, expanding production of wind power, expanding production of solar power and next-generation biofuels development reveals that a short term $\$ 100$ billion green economic recovery could create two million jobs opportunities across board. No definition of green jobs was presented.

Japan started communication around green jobs as early as 1994. Making reference to the green jobs potential in Japan, McClenahen [6] maintains that Japan had the potential to create 18,000 jobs in the constructions sector and 17,000 in environmental research alone in the period 1994-2000. The predictions were based on information from Japan's Environmental Protection Agency that assumed a constant annual growth rate of $8 \%$ and an annual investment of $\$ 959$ million in twin sectors identified.

Global Insight [7] was sponsored by the United States Conference of Mayors Climate Protection Centre to consider the USA Metro Economies focusing on Current and Potential Green Jobs in the USA Economy. The time frame looked at 30 years covering 2008 to 2038. The industry scope focused on renewable power generation, residential and commercial retrofitting as well as renewable transportation fuels. In the study, an attempt was made to define green jobs a definition of which is provided here. Green bobs were defined as:

Any activity that generates electricity using renewables or nuclear fuels, agriculture jobs supplying corn or soy for transportation fuel, manufacturing jobs producing goods used in renewable power generation, equipment dealers and wholesalers specializing in renewable energy or energy-efficiency products, construction and installation of energy and pollution management systems, government administration of environmental programs, and supporting jobs in the engineering, legal, research and consulting fields (Global Insight [7 p. 5]).

In terms of green job opportunities, Global Insight noted a figure of 751,000 as of 2006. From Global Insight's perspective, this figure amounted to less than $0.5 \%$ of total current jobs. Of the 751,000 green jobs, an estimated $85 \%$ was generated in metropolitan areas. For the 30 year horizon under consideration, an estimated 4.2 million new green jobs potential existed. A further breakdown on the spread of the green jobs potential was made as follows:

- Renewable Power Generation: 1.2 million green jobs;

- Residential and Commercial Retrofitting: 81,000 jobs - 36,000 in the residential sector and 45,000 in commercial; and

- Alternative Transportation Fuels: 1.5 million.

Ashkin [8 p. 19] establishes that one of the best definitions presented concerning green jobs is one by Carl Pope, an executive director of the Sierra Club who said: "A Green job has to do something useful for people, and it has to be helpful to, or at least not damaging to, the environment". The author sees 
green jobs as helping to create a powerful retaliation against climate change, with social and economic benefits that are multifaceted. The green jobs are local, and cannot be outsourced overseas. Aspects like installing solar panels need onsite labour whist retrofitting an office building is not something that can be done by remotely. The green jobs have an additional advantage in that they promise a middleclass wage, many do not require a college education, and are going to be in high demand in urban, as well as rural communities, an aspect that sits well with South Africa's poverty alleviation and jobs creation agenda.

A study by Bezdek [9] commissioned by American Solar Energy Society to look into 'Green Collar Jobs in the U.S. and Colorado: Economic Drivers for the 21 st Century' is another piece of work. The time line covered 2006 to 2030 with a focus on assessing direct job creation in renewable energy and energy efficiency. The study also looked at indirect green jobs potential all other sectors of the USA economy. Another definition on green jobs was conceptualised as direct job creation estimates that include employees working in one of the major renewable energy technologies like wind and solar power as well as employees working in industries that are entirely in the energy efficiency sector as well as a fraction of employees working in industries partially involved in energy efficiency.

To this end, green jobs opportunities in the renewable energy industry would include workers in the wind, solar, hydroelectric, geothermal, biomass, fuel cell, and hydrogen technology industries. Green jobs opportunities in the energy efficiency sector would include workers in areas like recycling, reuse or remanufacturing and a share of employees in industries that are partially in the energy efficiency sector like household appliances, vehicle production, and construction. Indirect green jobs potential also exists in sectors like restaurant staff or dry cleaners employed due to demand from directly created green jobs Bezdek [9].

The greatest percentage of jobs created in renewable energy and energy efficiency are, however, conventional jobs for accountants, engineers, computer analysts, clerks, factory workers, truck drivers and mechanics of which many employees in this group might not even realize that they owe their livelihood to renewable energy and energy efficiency. The green jobs potential in the wind sector can best be illustrated by considering cases from Denmark, Germany and Spain Boettcher et al. cited in (Kammen and Engel [10 p. 8]).

Bezdek [9] notes that in 2007, renewable energy was projected to be responsible for roughly 500,000 jobs, of which about half were indirect. More than $70 \%$ of the half a million jobs were in the biomass sector, with the largest share contributed by the ethanol and biomass power sub-sector. In terms of growth, the renewable energy sector was estimated to have grown $15 \%$ in two years (2006-2007), more than seven times as fast as the total U.S. economy growth. The energy efficiency sub-sector contributed about 8.5 million jobs with about 3.7 million of those being direct jobs in 2007 . More than $36 \%$ of the jobs were in the recycling, reuse and remanufacturing sector. Overall, Bezdek [9] projected total jobs related to renewable energy and energy efficiency by 2030 under three scenarios. 


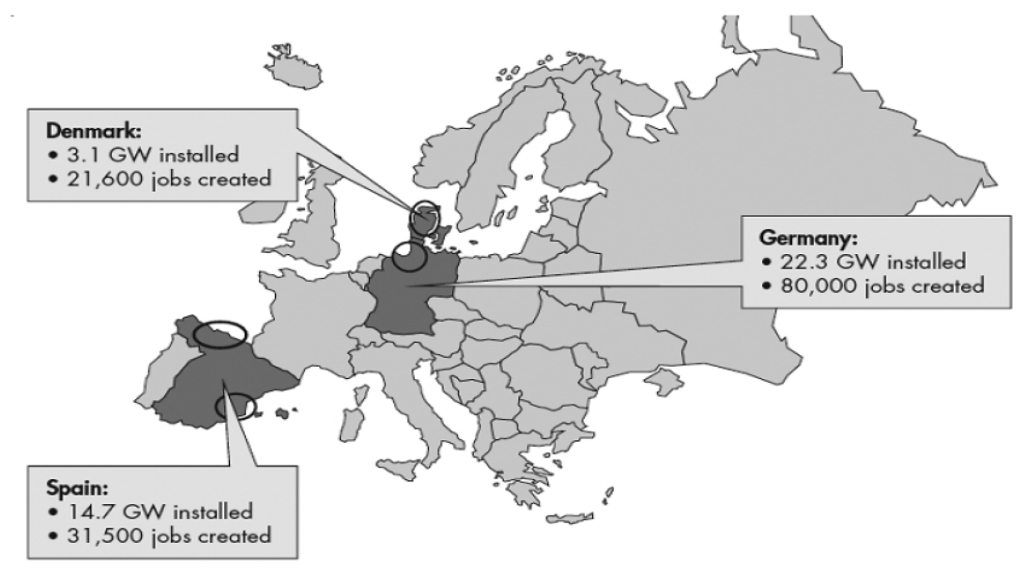

Figure 2: Installed capacity of wind energy and jobs created. Source: Boettcher et al. (cited in Kammen and Engel [10 p. 8]).

The work also proposes that the amount of jobs could go up depending on the aggressiveness of the key USA actors in promoting renewable energy and energy efficiency. Such a stance would lead to nearly six times as many jobs in 2030 . This might not be a difficult task to achieve given that President Obama has firmly placed renewable energy and energy efficiency initiative on top of the USA government agenda. Another earlier study to project green jobs from the clean energy industry Kammen et al. [11] is available for further reference.

South Africa talks of the concept environmental jobs McCutcheon [12], DoPW [13]. Environmental jobs must be seen as a component of Green Jobs. In this regard, the South African EPWPII identified environmental and other jobs from other sectors that include infrastructure, social and non-state. Forstater [14] sees a supportive role played by public sector employment programmes in creating green jobs and sustaining the environment. Hence a diagrammatic representation to show and differentiate between jobs is presented in Figure 3.

It is important to note that green jobs are an integral component of the greater jobs market. It is also critical to note that from Figure 3 green jobs are environmental jobs and not vice versa. In addition, at the core of green jobs are jobs oriented towards addressing $\mathrm{CC}$, chief among them, those from energy efficiency initiatives, alternative energy and any other addressing the need to move economies towards low carbon emission.

\section{Green jobs on the South African agenda}

Up until recently, there has not been a clear-cut national policy that addresses the concept of green jobs in South Africa. A number of national documents and high level politicians and business leaders have made ad hoc reference to the concept. Early work towards the conceptualisation of green jobs was done by the Department of Trade and Industry (DTI) in 2006. In a document entitled 


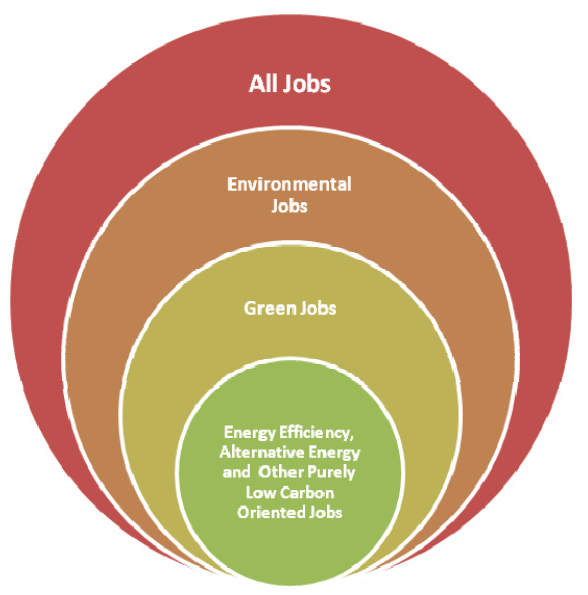

Figure 3: Conceptualisation of the jobs market. Source: author.

'Programme to Stimulate Growth in the South African Environmental Goods and Services Industry: The Green Jobs Concept', the DTI made reference to green jobs although no definition was provided. The DTI in collaboration with industry's intention was to evaluate the strengths and weaknesses of the Environmental Goods and Services (EGS) industry with a view to develop such a programme for South Africa (Forstater [14], DST [15]). The EGS industry was realised to be among the fastest growing industries globally, especially in line with environmental and climate change challenges. The DTI also noted that unlike other industrial sectors, the growth of the EGS industry is largely driven by the activities and policies of governments (DST [15]). Drawing from the UK, OECD and other global examples and classifications, the DTI list six sub-sectors as having potential for export growth and investment leading to the creation of green jobs in the country (DST [15 p. 3-5]) namely:

1. Environmental Services and Consultancy;

2. Water and wastewater treatment (to be prioritised);

3. Waste Management, Recovery and Recycling (to be prioritised);

4. Air Pollution Control;

5. Emergency response/clean-up; and

6. Clean Development Mechanism (CDM) and ?Energy Efficiency

Given the level of understanding pertaining to EGS in 2006, one cannot therefore blame the DTI for the strategic priorities made then. In fact, the DTI went further and prepared a road map for the recycling industry in South Africa (DTI [17]) that was published in January 2009. However, with the current government thinking in terms of the urgent need to address climate change, DTI and other government departments' priorities are likely to change and focus more on energy to include energy mix and energy efficiency. From the recycling industry road map, DTI indicated that its preferred approach to growing the EGS industry sector was to focus on and promote sub-sectors like cleaner production, 
energy co-generation and recycling. A full operating capacity from the recycling industry was estimated to "increase the number of direct employment opportunities by between 18,000 and 100,000 to offer 149,459 direct employment opportunities" (DTI [17 p. 1]) and up to 190,000 jobs by 2015 .

A draft discussion document towards 'The National Climate Change Response Policy' for South Africa presented during the National Climate Change Summit mentions the concept of green jobs twice. It has this to note concerning green jobs:

The In the USA and the UK and on the agenda of the G20 is the concept of a "green" or 'low carbon' path to economic recovery. Indeed, our President in the State of the Nations Address at the opening of Parliament in February, referred to the creation of 'green jobs' (emphasis is the author's) (DEAT [18 p. 12]).... South Africa's current energy supply crisis has created an opportunity for a thorough going transformation in the way that our economy and society is powered. Additionally, 'green jobs' and economic initiatives are being proposed worldwide as a key element of an economic recovery strategy (DEAT [18 p. 18]).

The 'Framework for South Africa's Response to the International Economic Crisis of February 2009 mentions 'green jobs' once. The concept is mentioned within the context of climate change, technology and industrial development. Item 3.6 in the Framework records that:

The parties recognise the opportunities in industries that combat the negative effects of climate change and believe that South Africa should develop strong capacity in these green technologies and industries. Accordingly it is agreed to develop incentives for investment in a programme to create large numbers of 'green jobs', namely employment in industries and facilities that are designed to mitigate the effects of climate change The Presidency [19 p.11].

The Framework for South Africa's Response to the International Economic Crisis set aside 787 billion Rand, a figure similar to President Obama's US\$787 billion. President Obama's $\$ 787$ billion Stimulus of 2008 was projected to create about 1.4 million green jobs in addition to 5 million jobs projected from another $\$ 150$ billion set aside for 2009-2018/19 for the clean energy sector Winkler [20]. Other things being equal, a clever guess could be that the 787 billion Rand stimulus for South Africa could generate a similar number green jobs (Creamer [21]).

In a budget vote speech made by the Minister for Agriculture, Forestry and Fisheries to Parliament in June 2009, the concepts of green jobs was alluded to. Minister Joemat-Petersson indicated that the government needs "to develop appropriate responses and invest in cleaner production methodologies, create 
green job opportunities, promote innovation and apply scientific technology in the production processes" (Joemat-Petersson [22 p. 5]).

The concept of environmental jobs has been formally recorded in the Expanded Public Works Programme (EPWP) (DoPW [13]). The EPWP is one of the key poverty and hunger alleviation programmes that the government has been driving vigorously. Significant progress has been made towards achieving the EPWP target of creating more than a million net new work opportunities over the five-year period of the programme. The EPWP recorded up to 281,626 jobs (38\% of the targeted 750,000 work opportunities) as having been created through the Infrastructure Sector Programme (ISP) (The Presidency [23 p. 9]).

The EPWP is run under four distinctive sectors namely: environment and cultural, social, economic and infrastructure sectors. These sectors comprise a number of government departments with one department nominated to lead each sector (DoPW [13]). The former Department of Environmental Affairs and Tourism (DEAT) was nominated to lead the Environmental and Cultural Sector consisting of three other departments then: Water Affairs and Forestry, Arts and Culture as well as Agriculture (DoPW [13]).

The job opportunities were highlighted to be created in five key programme areas including Sustainable Land Based Livelihoods, Working for the Coast, People and Parks, Working for Tourism and Working on Waste. The sustainable land based livelihoods sub-sector addressed job opportunities under programmes that included Working for the Land, Working for Water, Working for Wetlands and Working on Fire (DoPW [13]).

The President of the Republic of South Africa, Jacob Zuma announced an estimated 500,000 jobs had to be created by December 2009. This was quiet a bold move given that the world over every economy was battling with the financial crisis and job losses. The road map informing the proclamation by the President is enshrined in the Expanded Public Works Programme II (EPWPII) whose job projections and details discussed in much depth in the next sections. The total full time job equivalent (including those from the environmental sector) is presented in Figure 4.

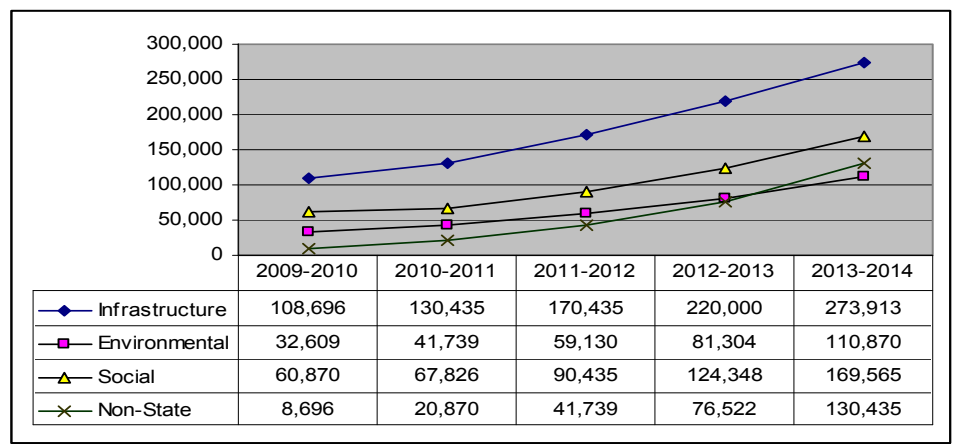

Figure 4: Total full time equivalent (job) by sector. Source: author. 


\section{Future of green jobs in South Africa}

The success of the green jobs initiative in South Africa is dependent upon a wide range of factors and actors. Organised government, as well as the private sector must play a pivotal role supported by the NGO and donor community. Changes in the decisions, practices and behaviours of managers, workers and consumers will also add value to this transition process.

A green South African economy will create demand for workers, many of them in skilled trades or professions, and filling these positions will require adequate training programs. At the cutting edge of technology development for wind turbine or solar PV design, for instance, specialization has progressed to the point where universities need to consider offering entirely new study fields and majors. Several countries have reported that a "skills gap" already exists between available workers and the needs of green industries (UNEP et al. [1 p. 25]):

- A 2007 survey of Germany's renewables industry concludes that companies in this field are suffering from a shortage of qualified employees, and especially those needed in knowledge-intensive positions.

- The Confederation of British Industry has expressed concern that sectors going green are struggling to find technical specialists, designers, engineers, and electricians.

- In the United States, the National Renewable Energy Laboratory has identified a shortage of skills and training as a leading barrier to renewable energy and energy-efficiency growth.

The challenges highlighted above are also present in South Africa. As a high GHG emitter, the country must move fast to engage with mechanisms leading to transition to a green and low carbon economy. The upcoming national green jobs strategy and other planned policy and legal frameworks must be finalised without delay. The greatest challenge will still remain the skills gap.

\section{References}

[1] UNEP/ILO/IOE/ITUC. Green Jobs: Towards Decent Work in a Sustainable, Low-Carbon World. 2008. Nairobi, UNEP/ILO/IOE/ITUC.

[2] DEAT. Long Term Mitigation Scenarios Strategic Options for South Africa. 2007. Pretoria, Government Printer.

[3] Chapple, K. Defining the green economy: A primer on green economic development. 2008. Berkeley, Centre for Community Innovation.

[4] WWF. Low Carbon Jobs for Europe: Current opportunities and future prospects. 2009. Brussels, WWF European Policy Office.

[5] Pollin, R.; Garrett-Peltier, H.; Heintz, J.; Scharber, H. Green recovery: A program to create good jobs and start building a low-carbon economy. 2008. Massachusetts Amherst, Center for American Progress.

[6] McClenahen, J. Green jobs in Japan. Industry Week, 89-90. 1994. 
[7] Global Insight. U.S. Metro Economics: Current and potential green jobs in the U.S. economy. 2008. Lexington, Global Insight.

[8] Ashkin, S. The green revolution: Not your great-grandfather's revolution. 2007. New York, The Green Scene.

[9] Bezdek, R. Renewable energy and energy efficiency: Economic drivers for the 21st Century. 2007. New York, American Solar Energy Society.

[10] Kammen, D. M.; Engel, D. Green jobs and the clean energy economy. 2009. Berkeley, Copenhagen Climate Council.

[11] Kammen, D. M.; Kapadia, K.; Fripp, M. Putting renewables to work: How many jobs can the clean energy industry generate? 2006. Berkeley, University of California.

[12] McCutcheon, R. T. Employment Generation in Public Works: Recent South African Experience. Construction Management and Economics 2001, 19, 275-284.

[13] DoPW. Environment and Culture Sector Plan. 2004. Pretoria, Department of Public Works.

[14] Forstater, M. Green Jobs: Public Service Employment and Environmental Sustainability. Challenge 2006, 49, 58-72.

[15] DST. Green jobs and industries for South Africa (Green-JISA). 2009. Pretoria, Department of Science and Technology.

[16] DTI. Programme to stimulate growth in the South African environmental goods and services industry: The green jobs concept. 2009. Pretoria, Department of Trade and Industry.

[17] DTI. Proposed road map for the recycling industry: A recycling industry body (RIB) with relevant working groups. 2009. Pretoria, Department of Trade and Industry.

[18] DEAT. The National Climate Change Response Policy: Discussion Document for the 2009 National Climate Change Response Policy development Summit, Gallagher Convention Centre, Midrand, 3-6 March 2009. 2009. Pretoria, Department of Environmental Affairs and Tourism.

[19] The Presidency. Framework for South Africa's Response to the International Economic Crisis - 19 February 2009. 2009. Pretoria, The Presidency.

[20] Winkler, H. Working for Energy. http://www.engineeringnews.co.za/ article/working-for-energy-2009-02-20 (accessed 13 September 2009).

[21] Creamer, T. 'Green jobs' plan in SA stimulus framework. http://www.engineeringnews.co.za/article/green-jobs-plan-included-in-sastimulus-framework-2009-02-23 (accessed 30 August 2009).

[22] Joemat-Petersson. SA: Joemat-Petersson: Budget vote speech by the Minister for Agriculture, Forestry and Fisheries to Parliament (17/06/2009). 2009. Pretoria, Ministry of Agriculture, Forestry and Fisheries.

[23] The Presidency. ASGISA Annual Report 2007. 2007. Johannesburg, The Presidency. 